\title{
Mission Impossible? Preventing discrimination on grounds of disability of foetuses with Down syndrome in Spain after the emergence of non-invasive prenatal testing.
}

\section{Begoña Rodriguez Diaz}

\begin{abstract}
This article analyses the current situation of discrimination towards foetuses with Down syndrome in Spain, both legally and through the medical practice, pointing out how this discrimination breaches the United Nations Convention on the Rights of Persons with Disabilities (CRPD), ratified by Spain, according to the Committee of the CRPD.

This work argues that an eventual modification of the Spanish abortion legislation (in appeal before the Constitutional Court) might not be enough to prevent the said discrimination due to the emergence of the non-invasive prenatal testing (NIPT). It explores the challenges introduced by the noninvasive prenatal testing and the relationship between a prenatal diagnose of a disability (DS in particular) and termination of pregnancy rates. Health practitioners, mainly through the communication of the diagnose, play a significant role in the bias against the Down syndrome population that leads to discrimination. Consequently, this article suggests the need for a different approach towards a DS diagnose, more accurate, positive and based on the actual experience of individuals with DS and their families.
\end{abstract}

\section{Keywords}

Discrimination, disability, Down syndrome, non-invasive prenatal testing (NIPT), selective termination of pregnancy.

\section{Corresponding author:}

Begoña Rodríguez Díaz, Universidad Francisco de Vitoria, Carretera PozueloMajadahonda, km.1.800, Madrid 28,223 (Spain).

Email: b.rodriguez@ufv.es 


\section{Mission Impossible? Preventing discrimination on grounds of disability of foetuses with Down syndrome in Spain after the emergence of non-invasive prenatal testing}

\section{Introduction}

Unborn children with Down Syndrome (DS) have been discriminated in Spain on grounds of their disability since 1985 . The Criminal Code considered the abortion an offence unless there were special circumstances, one of them being the risk of 'serious mental or physical disabilities' in the foetus, where termination prior to the $22^{\text {nd }}$ pregnancy week would not be considered punishable.

In current Spanish legislation regarding termination of pregnancy (TOP), Act 2/2010, abortion at request of the pregnant woman is considered a right (within the fundamental rights in the field of sexual and reproductive health) if performed in the first fourteen weeks of the pregnancy. An extended deadline is given in case there is a 'risk of serious anomalies in the foetus' and no time-limit when 'an extremely serious an incurable illness is detected in the foetus' (art. 15).

Having ratified the International Convention on the Rights of Persons with a Disability (CRPD) in 2007, the Act 2/2010 is in breach of this international commitment. The Committee on the CRPD accordingly recommended in 2011 'that the State party abolish the distinction made in Act 2/2010 in the period allowed under law within which a pregnancy can be terminated based solely on disability' ${ }^{2}$. Again, very recently, the Committee expressed its concerns about 'the lack of progress to implement the previous recommendations of the Committee to abolish legal provisions that reinforce a negative perception of disability by providing for the late termination of pregnancy based on foetal impairment' ${ }^{3}$ and therefore recommended to 'abolish any distinction by law to the period within which a pregnancy can be terminated based on a potential foetus impairment (...), as these contribute to a climate of stigma against disability that can lead to discrimination. ${ }^{4}$

Nine years after the Act 2/2010 (that has remained unchanged despite the CRPD Committee Reports) we are facing a new challenge regarding the discrimination of foetuses on grounds of disability: the misuse of non-invasive prenatal testing (NIPT). Designed to detect chromosomal abnormalities, and DS in particular (Gil et al., 2015) through a simple blood test in the early weeks of the pregnancy they are having a radical influence in the increase of terminations of DS foetuses.

Globally, selective abortion rates are 60-90 percent when a foetus is diagnosed DS. In some countries such as Iceland (Klucznik and Slepian, 2018) and Denmark ${ }^{5}$, the rates are already near 100 percent. In France (Dommergues et al., 2010) and in England (Morris and Springett, 2014), environ $90 \%$ of diagnosed foetuses with DS end up as TOP. In the US, the rate is around $65-75 \%$ (Natoli, 2012). In Spain, it is nearly 95\% (Vargas Aldecoa, 2015).

The rate of babies born with DS in Spain has radically decreased. The figures' evolution runs in parallel to the changes to abortion legal provisions: before 1985 (when TOP was decriminalised under certain circumstances such as serious defects in the foetus) there were 14.78 babies with DS per every 10,000 newborns. After 1985 and before the radical modification of the abortion legislation in 2010, the rate was 9.93 per 10,000 newborns. In 2011 this rate decreased to 4.84

Rodríguez Díaz, B, Mission Impossible? Preventing discrimination on grounds of disability of foetuses with Down syndrome in Spain after the emergence of non-invasive prenatal testing, International Journal of Discrimination and the Law XX (X), pp. 1-22. Copyright (C) [2020] (Rodríguez Díaz, B). DOI: [10.1177/1358229120902654] 
(Bermejo et al., 2012, p. 93). This is due to the increase of TOP of foetuses with DS and the improvement in the prenatal screening techniques (Bermejo et al., 2011, p. 105).

The object of this paper is to raise awareness of the current discrimination on grounds of disability for foetuses with DS in Spain both legally and through the medical practice and to reflect on how to prevent the aforementioned discrimination. We are going to focus on the Spanish scenario but many of our conclusions might be valid for other countries with a similar abortion legislation or practice.

First, we will briefly present the evolution of the prenatal testing in order to understand the challenges presented by the new NIPT. Second, we will show some figures about the rate of terminations of diagnosed DS foetuses. Third, we will explain the current Spanish legislation and practice concerning selective termination on grounds of a DS diagnose and we will analyse the most likely scenarios in the near future. Finally, we will reflect on what can be done to avoid selective terminations that constitute discrimination on grounds of disability.

It should be noted that this paper is drafted from a legal perspective. However, it is also drafted from the perspective of a mother of a child with DS, whose personal experience has undoubtedly enriched her views about the rights of people with disabilities.

\section{Evolution of prenatal testing}

Although this study aims to assume a legal perspective, it is necessary to offer a brief scientific explanation of the different available prenatal techniques. While the traditional diagnostic techniques require to be performed at a later stage of the pregnancy, the NIPT offer a much earlier detection of foetal anomalies, in particular DS, with a similar accuracy. This is highly relevant as eventually removing the discrimination in law towards foetuses with disabilities might not be enough to prevent it: women who are given an accurate rate of a foetal anomaly likelihood in the early weeks of the pregnancy might decide to terminate on these grounds and they could do so within the general deadline without stating the cause. This is the main challenge of the NIPT regarding disability-related abortion, others including its misconception as a safer alternative to diagnostic techniques and its cost, which makes the inclusion of these techniques into the routine pregnancy screening tests not unthinkable.

There are two main categories of prenatal techniques (Collins and Impey, 2012): the invasive techniques: chorion biopsy, amniocentesis, foetal blood sampling, biopsy of foetal tissue and embryofetoscopy, and the non-invasive techniques: ultrasound, Doppler, maternal blood (biochemical markers) and maternal blood (cell-free fetal DNA or cffDNA). Each of them shall be performed at specific times throughout the gestational period. An important distinction must be made regarding the nature of the techniques: while the prenatal diagnostic techniques allow us to identify foetal anomalies such as DS, the screening techniques only allow to suspect a possible foetal anomaly, that is, the likelihood of the foetus of being affected by the considered anomaly (American College of Obstetricians and Gynecologists, 2019).

In order to accurately diagnose DS (99.9\%) the most common technique is the amniocentesis which has a $2 \%$ risk of miscarriage.

Being non-invasive, the screening tests are safer (no risk at all), although they only allow us to detect the risk of the foetus to have DS. The accuracy depends on the kind of screening, combining two or more techniques.

Rodríguez Díaz, B, Mission Impossible? Preventing discrimination on grounds of disability of foetuses with Down syndrome in Spain after the emergence of non-invasive prenatal testing, International Journal of Discrimination and the Law XX (X), pp. 1-22. Copyright (C [2020] (Rodríguez Díaz, B). DOI: [10.1177/1358229120902654] 
In Spain the routine screening test performed to detect DS combines an ultrasound (to measure nuchal translucency thickness and nasal bone) and maternal blood test (to detect human chorionic gonadotropin and pregnancy-associated plasma protein-A). It allows to detect more than $90 \%$ of the foetuses with DS, being the false-positive rate around 2.5\% (Gracia Manzano, 2017). Those women who have a positive result are offered further testing to accurately diagnose the anomaly (mainly amniocentesis).

However, prenatal genetic screening has changed dramatically in the last few years, driven primarily by the introduction of cell-free DNA (cfDNA) testing into clinical practice in 2012 (Gray and Wilkins-Haug, 2018): it is a non-invasive technique consisting in a simple blood test taken in the first trimester of the pregnancy. It uses 'massively parallel sequencing analysis of cell-free fetal DNA (cffDNA) in maternal plasma, which contains cffDNA originating from the trophoblast mixed with cell-free maternal DNA' (Petersen et al., 2017, p.691e1). Initially, four commercial labs offered cffDNA testing, with detection rates for trisomy 21 of $99 \%$, trisomy 18 of $97-99 \%$ and trisomy 13 of 80-99\% (Gray and Wilkins-Haug, 2018). Focusing on DS, the false positive rate (FPR) is $0.1 \%$, meaning that the cfDNA test is positive for an abnormality in $0.1 \%$ of the cases but the foetus is later determined to be unaffected. Furthermore, according to studies developed in the UK (Gil et al., 2016, p.48), the FPR is as low as $0.03 \%$ : 'If cfDNA testing had been confined to screening for trisomy 21 , the FPR would have been $0.03 \%(1 / 3564)$ '. Based on these data, it has been argued that its accuracy detecting this chromosomal abnormality is very similar to very precise diagnostic invasive techniques such as amniocentesis but entraining no risk and hence 'it has been advertised repeatedly in the press as the method to replace amniocentesis' (Borrell and Stergiotou, 2015, p. 508). According Borrell (2018), this misconception of cfDNA as a safer alternative to amniocentesis is based on its commercial name (NIPT) and it has been used for marketing purposes, implying invasive procedures will not be required. Most experts (within them, Gray and Wilkins-Haug, 2018; Petersen et al., 2017; Smith et al., 2014) agree, however, that NIPT cannot replace diagnostic invasive techniques to confirm foetal chromosomal disorders. Besides, the NIPT have been correctly validated for trisomy 21 singleton foetuses (99\%) but not for twins and are not able to detect other aneuploidies (Borrell, 2018; Gray and Wilkins-Haug, 2018).

The cfDNA tests present a side consequence: the so-called "hidden losses": 'Pregnancy termination without karyotype confirmation has been reported in $6-20 \%$ of cfDNA positive results, decreasing to a $4 \%$ in cases with normal ultrasound.' (Borrell, 2018, p. 6).

The NIPT could soon become the first-line screening test for all women (Gray and WilkinsHaug, 2018). In 2018, cfDNA primary screening has been implemented in the public health system in Netherlands and Belgium, while it was introduced as second tier screening in Finland and Denmark, and as contingent screening in Switzerland (Borrell, 2018). It has also been introduced in the NHS Wales as an alternative to invasive procedures ${ }^{6}$ and as an additional option to women with singleton pregnancies who are deemed at higher chance following the combined or quadruple screen in England ${ }^{7}$. In France, under certain conditions, women are refunded the cost of the NIPT ${ }^{8}$.

In Spain, the public health system is decentralized. Most Autonomous Communities offer the NIPT to women in high risk of a foetal chromosomal abnormality in order to reduce the number of invasive and riskier techniques but not as a primary screening test available universally.

NIPT can also be accessed privately at a cost of about 500 euros. This cost has been highlighted by the academia, thus considering them not to 'be used as the primary screening method within

Rodríguez Díaz, B, Mission Impossible? Preventing discrimination on grounds of disability of foetuses with Down syndrome in Spain after the emergence of non-invasive prenatal testing, International Journal of Discrimination and the Law XX (X), pp. 1-22. Copyright (C) [2020] (Rodríguez Díaz, B). DOI: [10.1177/1358229120902654] 
normal pregnancy population' (Vicie et al., 2017, p. 733). However, it has been argued that 'using empirical data on uptake of testing, we have shown that NIPT can be provided effectively, and without increasing costs, as part of a publicly funded national DS screening pathway with the provision of NIPT testing in a public sector laboratory' (Chitty et al., 2016, p. 11). In this scenario, it seems very likely that NIPT will be included as part of the routine screening tests for every pregnant woman.

\section{Down syndrome diagnoses and termination of pregnancies}

Prenatal testing has both advantages and disadvantages. Knowing the foetus condition can help the expectant parents to prepare themselves for the special needs their baby may have. Also, some conditions can be treated before birth or shortly after. In contrast, most genetic disorders cannot be treated or corrected, and a positive result may cause anxiety to the prospective parents. On our view the most important disadvantage of these prenatal tests is the clear relationship between diagnosed genetic disorders and TOP rates in the assumption that a life with a disability is less worth to be lived. Let us remember that some scientists consider 'immoral' not to abort a diagnosed DS baby and simply suggest "Abort it and try it again" (Dawkins, 2014).

As the International Bioethics Committee (IBC, 2015) has pointed out: 'screening is only justified if the usefulness of the intervention has been proven, and the advantages for the participants clearly outweigh the disadvantages' (par. 87). 'The situation is different when the purpose is not health gain but to decide, according to many domestic legislations, whether to carry a pregnancy to term, as it may be the case with serious foetal abnormalities. If they carry to term, it allows those involved to prepare for the birth of a sick or disabled child. If they do not, they avoid giving birth to a sick or disabled child' (IBC, 2015, par. 88).

Jotkowitz and Zivotofsky (2010, p. 149) highlight that: 'While not all prenatal testing done for conditions that currently have no prenatal therapeutic intervention are performed for the sake of abortion, the vast majority are. This has resulted in a large decrease in the birth incidence of DS (...) If the new tests are safer for the fetus, less invasive for the woman, and provide a diagnosis earlier in the pregnancy, possibly even before the woman begins to "show", there is every reason to believe that the percentage of abortions for conditions such as DS, deafness, and dwarfism, will only rise'.

It has been argued that prenatal screening tests are widely used with the eugenic purpose of decreasing the population presenting chromosomal abnormalities such as DS (who are the main population targeted) and even to make the population with DS disappear. This fear has been pointed out both from the academia (Skotko, 2009) and from organisations representing people with DS (for instance, at the congress "A world without DS?" held in March 2017 and active ever since $^{9}$ ). In the UK there is a social media campaign called "Don't screen us out", 'supported by a collection of people with DS, families and DS advocate groups' that 'have come together to highlight the serious concerns around the introduction of second-line cfDNA screening in the $\mathrm{UK}^{\prime} 10$

Let us bear in mind that 'the risk of a DS baby increases sharply with age' (Jotkowitz and Zivotofsky, 2010, p. 148). As the maternal age at the time of conception has increased in Europe in the last 20 years, there has been an increase of $10 \%$ of number of pregnancies with DS (World Health Organisation, 2018). 'However, development and the increasingly widespread practice of

Rodríguez Díaz, B, Mission Impossible? Preventing discrimination on grounds of disability of foetuses with Down syndrome in Spain after the emergence of non-invasive prenatal testing, International Journal of Discrimination and the Law XX (X), pp. 1-22. Copyright (C) [2020] (Rodríguez Díaz, B). DOI: [10.1177/1358229120902654] 
prenatal screening followed by TOP have resulted in stable live birth prevalence' (Vicie et al., 2017, p.731).

The figures of abortion following a DS diagnose have already been shown and they reveal the dimension of the issue object of this paper. Let us be reminded that in many European countries, included Spain, the rate is environ $90 \%$.

\section{The Spanish legislation and medical practice}

\section{The abortion legislation regarding foetuses with a disability}

In this section we are presenting the Spanish legislation regarding abortion of foetuses with a physical or intellectual impairment in order to show that since abortion was first decriminalised in Spain, the Spanish legislation has been discriminatory against unborn children presenting an impairment such as Down syndrome. We will argue this constitutes a breach of international treaties, mainly the UN Convention on the Rights of Persons with Disabilities.

There are two moments to be considered regarding the topic of this study:

The Criminal Code from 1985. In 1985, for the first-time abortion was decriminalised in Spain if performed under certain circumstances. One of them was the presence of 'serious physical or mental problems in the foetus'. This modification of the Criminal Law was contested before the Constitutional Court on the basis that art. 15 of the Spanish Constitution states: 'All have the right to life'. Although the Constitutional Court (CC) ruling considered it to be constitutional, it is worth highlighting the following: first, the Court recognizes:

'the life of the unborn child, (...) is a legal right constitutionally protected by art. 15 of our fundamental regulation. (...) this protection which the Constitution dispenses to the unborn child implies two obligations for the State in general terms: that of refraining from interrupting or hindering the natural gestation process, and that of establishing a legal system for the defence of life (...). This does not mean that said protection needs to be absolute; in fact, as occurs with all constitutionally recognised rights, in specific cases it may and even should be subject to restrictions, as we shall see below. (.... $)^{11}$.

Secondly, the CC found that the presence of a serious defect in the foetus could justify a restriction to the right to life of the unborn child. The argumentation of the $\mathrm{CC}$ is based on the personal and economic burden prospective parents could experience should the child be born with a serious defect. This reasoning has contributed to a climate of stigma against disability, by highlighting the challenges of parenting a child with a serious defect or disability: The CC considered 'that the use of a criminal penalty would entail the imposition of a conduct which exceeds what is normally required of a mother and the family. The previous statement takes into account the exceptional situation in which parents find themselves, and in particular the mother, and which is frequently aggravated in many cases by a lack of state and social provisions which would contribute significantly to mitigating the assistance requirements of the case and to removing the insecurity inevitably felt by the parents with regard to the fortunes of the affected child, given the seriousness of its condition in the event of survival (...) insofar as progress is made in enforcing preventive policy and in the generalisation and intensity of the assistance in a social State (...) this will decisively contribute to preventing the situation on which decriminalisation is based ${ }^{12}$.

Rodríguez Díaz, B, Mission Impossible? Preventing discrimination on grounds of disability of foetuses with Down syndrome in Spain after the emergence of non-invasive prenatal testing, International Journal of Discrimination and the Law XX (X), pp. 1-22. Copyright (C) [2020] (Rodríguez Díaz, B). DOI: [10.1177/1358229120902654] 
The Act 2/2010. The Act 2/2010 meant a radical change concerning the abortion provisions in Spain. Far from not being considered a crime, it is currently considered a fundamental right of the woman if performed in the first 14 weeks of the pregnancy. This consideration as a 'fundamental' right of the woman plays a vital role since the Act 2/2010 states that it prevails over the protection that a prenatal life has right to (and though expressly recognizing prenatal life as a legally protected interest). The right to abort at the request of the pregnant woman is thus included within the fundamental rights concerning the sexual and reproductive health (art. 1 Act $2 / 2010$ ). Beyond the first 14 weeks of pregnancy abortion can be legally performed if the foetus has 'serious impairments' (until the $22^{\text {nd }}$ week) or an 'extremely serious incurable illness' (no deadline), art. 15 Act 2/2010.

\section{The breach of international treaties}

Validly concluded international treaties form part of the Spanish internal legal order since they are officially published in the Spanish Official State Gazette (art. 96.1 Spanish Constitution). Once they become part of the domestic legal order, the supremacy of the international treaties over non-constitutional domestic provisions has been expressly recognized by the Spanish Constitution (art. 96) and by the Act 25/2014 (art. 31), as required by the 1969 Vienna Convention on the Law of the Treaties (art.27).

As a matter of course, Spanish courts apply international treaties provisions ${ }^{13}$, having recognized that individuals may rely on them to invoke direct rights should them be drafted in precise, complete and unconditional terms (Paniagua Redondo 1991, p. 925).

Spain's ratification of the UN Convention on the Rights of Persons with Disabilities was published on the Boletin Oficial del Estado num. 96 on April the $21^{\text {st }} 2008$, long before the entry into force of the Act 2/2010. As we have described, the Act 2/2010 provides an extended deadline to perform an abortion where the foetus presents a serious impairment. This clearly goes against the CRPD. First of all, because from a rigorous application of the treaties interpretation rules according to the 1969 Vienna Convention it is evident that the right to life should be protected to every 'human being' (art. 10 CRPD) 'on an equal basis with others' (Rodríguez Díaz, 2017, p. 414) and therefore, in every stage of the life of the human being, also prenatal life, equal treatment re the said protection should be granted: unborn foetuses with disabilities should enjoy their right to life 'on an equal basis' with foetuses without disabilities.

Secondly, as Palacios argues, the breach of the CRPD by art. 15 of Act 2/2010 is manifest regardless of the non-consideration of the foetus as a person under Spanish domestic law $^{14}$ (Palacios, 2010, p. 55): the CRPD not only forbids discrimination towards persons with disabilities but entails a much wider concept including 'all discrimination on the basis of disability' (art. 5) which is defined in art. 2 as "any distinction, exclusion or restriction on the basis of disability which has the purpose or effect of impairing or nullifying the recognition, enjoyment or exercise, on an equal basis with others, of all human rights and fundamental freedoms". The General Principles set on art. 3 CRPD and non-discrimination in particular (art. 3b), 'must permeate the whole of the Convention' (Allain J., 2009, p. 21) and hence, art. 10, when interpreting it.

Rodríguez Díaz, B, Mission Impossible? Preventing discrimination on grounds of disability of foetuses with Down syndrome in Spain after the emergence of non-invasive prenatal testing, International Journal of Discrimination and the Law XX (X), pp. 1-22. Copyright (C) [2020] (Rodríguez Díaz, B). DOI: [10.1177/1358229120902654] 
Therefore, we argue that the distinction made in art. 15 of Act 2/2010 is a breach of the CRPD which, as an international treaty, is hierarchically superior to domestic law.

Also we should bear in mind that the CRPD indicated a shift from the medical model to the social model of disability, that is, "from viewing persons with disabilities as "objects" of charity, medical treatment and social protection towards viewing persons with disabilities as "subjects" with rights, who are capable of claiming those rights and making decisions for their lives based on their free and informed consent as well as being active members of society ${ }^{15}$. Therefore, disability is defined as an 'evolving concept' resulting from 'the interaction between persons with impairments and attitudinal and environmental barriers that hinders their full and effective participation in society on an equal basis with others' (CRPD preamble, e).

If we analyse the subject of eugenic abortion on grounds of disability from the social model, we can clearly conclude that it is the interaction between the impairments (or the functional diversity of the persons) and an attitudinal barrier (a legislator decision based upon prejudices and biases such as the less worthy lives of people with impairments or the burden they might entail for their parents and the society) what prevent them to ensure their right to life protected on an equal basis with others (without functional diversity) (Palacios, 2010, p. 53).

This conclusion is consistent with the interpretation made by the CRPD Committee, which urged Spain in $2011^{16}$ to remove the distinction made in Act 2/2010 in the period allowed under law within which a pregnancy can be terminated based solely on disability and again in the last report (2019), pointing out that it contributes 'to a climate of stigma against disability that can lead to discrimination' 17 .

Article 15 of the Act 2/2010 is not the only way Spain is breaching the CRPD. Let us remember that State parties in the said Convention are not only bound not to contradict the CRPD through legislation (art. 4.1.a) but also to take all appropriate measures to put an end to all practices that constitute a discrimination on grounds of disability (art.4.1b), to make sure the public institutions comply with the CRPD (art.4.1.d) and also private companies and organisations (art. 4.1.e).

As we will argue below, the healthcare provided by the national healthcare system discriminates on grounds of disability and therefore constitutes a breach of the CRPD on behalf of Spain.

Equally, the Spanish legislation breaches other international treaties such as the Oviedo Convention on Human Rights and Biomedicine (ratified by Spain on 23 July 1999 and published in the Boletín Oficial del Estado n. 251 on 20 October 1999): 'Any form of discrimination against a person on grounds of his or her genetic heritage is prohibited' (art. 11). Although the wording of art. 11 uses the term 'person' and we cannot consider an unborn foetus a person under domestic law, we support a holistic approach to this international treaty in conjunction with other treaties protecting general interests of the international community (Rodrigo \& Abegón, 2017). Let us bear in mind that its purpose is to "protect the dignity and identity of all human beings and guarantee everyone, without discrimination, respect for their integrity and other rights and fundamental freedoms with regard to the application of biology and medicine" (art. 1). The Preamble reinforces this idea as it highlights 'the need to respect the human being both as an individual and as a member of the human species' and recognises 'the importance of ensuring the dignity of the human being'. The primacy of the human being is emphasised in art. 2: 'The interests and welfare of the human being shall prevail over the sole interest of society or science'.

Rodríguez Díaz, B, Mission Impossible? Preventing discrimination on grounds of disability of foetuses with Down syndrome in Spain after the emergence of non-invasive prenatal testing, International Journal of Discrimination and the Law XX (X), pp. 1-22. Copyright (C [2020] (Rodríguez Díaz, B). DOI: [10.1177/1358229120902654] 
As concerns our object of study, the discrimination of foetuses with DS in their right to life in Spain, we argue that Act 2/2010 holds a clear discrimination on grounds of the genetic heritage of unborn human beings and, thus, breaches the Convention on Human Rights and Biomedicine.

\section{The medical practice}

In Spain the routine screening tests provided in the early weeks of the pregnancy are prenatal detection techniques that require invasive techniques to accurately confirm an eventual diagnose of a chromosomal abnormality such as DS. The NIPT are not offered universally but only to women with a result of high risk of having a baby with such an abnormality according to screening test and only in some Autonomous Communities.

The informed consent form given to pregnant women having a routine screening test states that: 'the final goal of this test is to find out about the chromosomal integrity of my child and eventually to allow me to take up the Law of Voluntary Pregnancy Interruption. ${ }^{, 18}$

This statement implicitly reveals that a life with a genetic disorder or chromosomal abnormality such as DS is considered more likely to be terminated. Furthermore, studies have shown (Vargas Aldecoa, 2015, p. 238) that health practitioners in Spain encourage the termination for half of the cases of foetuses with DS while actively try to convince expecting mothers towards an abortion in a minority of cases.

This is not happening only in Spain: more than ten years ago Dixon argued the medical profession was encouraging abortion of DS foetuses: 'There are numerous contributing factors to what some may call a high termination rate of foetuses that have tested positive for Down Syndrome. One major factor is the direct and indirect influences of medical professionals, which include genetic counsellors, family physicians and obstetricians and gynaecologists' (Dixon, 2008, p. 3).

The healthcare professionals might be influenced by successful "wrongful birth" cases in which different Courts have awarded damages to parents whose babies with DS were not diagnosed in time so allowing for termination of their pregnancy (Martínez-Pujalte, 2016, p. 160).

On this matter both the medical practice and the judiciary are going against the CRPD, as they either consider the life of a foetus with DS is less likely to be accepted by prospective parents (and so suggesting abortion), or it is less worthy than able-lives (and hence encouraging abortion), or it implies an emotional and economic burden for their parents (and consequently, awarding damages). As we will further explain in subsequent sections, all these constitute a breach of the obligations assumed by Spain as State party of the CRPD (art. 4).

\section{The long-awaited ruling of the Constitutional Court regarding the Act 2/2010}

The Act 2/2010 was contested before the CC in 2010. While almost ten years later it has not ruled yet, we aim to offer a speculative analysis about the foreseeable future and to reflect briefly on the most likely outcomes, which are:

- The CC may declare the Act 2/2010 is constitutional in its whole.

- The CC may rule against considering TOP a fundamental woman's right to be enjoyed in any circumstance.

Rodríguez Díaz, B, Mission Impossible? Preventing discrimination on grounds of disability of foetuses with Down syndrome in Spain after the emergence of non-invasive prenatal testing, International Journal of Discrimination and the Law XX (X), pp. 1-22. Copyright (C) [2020] (Rodríguez Díaz, B). DOI: [10.1177/1358229120902654] 
- The CC may rule that TOP based on physical or mental impairment should be performed within the general deadline and not within an extended one.

The first outcome would contradict previous constitutional doctrine affirming the life of the unborn child is a legal right constitutionally protected by art. 15 of our fundamental regulation. Regarding the life of unborn disabled children, the $\mathrm{CC}$ had ruled the protection given to unborn children's lives should not be considered absolute. However, the grounds given by the CC to allow the abortion in case of physical or mental defects in 1985 made reference to the economic burden the baby would create due to the lack of support. This argument needs to evolve and adjust to the social model of disability where the economic reasons should never suffice to refuse the protection of the rights of persons with disabilities. As we have explained in previous sections, persons with disabilities can no longer be conceived as "objects" of charity, medical treatment and social protection but as "subjects" of rights. The social model of disability "places the moral responsibility on society to remove the burdens which have been imposed, and to enable disabled people to participate' (Shakespeare, 2013, p. 217). The Act 2/2010 was passed once the CRPD was in force in Spain and it clearly contradicts it. It is difficult to argue how to legally maintain this discrimination.

In the second scenario, if the $\mathrm{CC}$ concludes that TOP is not a fundamental right of the pregnant woman to be enjoyed in any circumstance, it would mean freely terminating the pregnancy before a certain deadline would no longer be legal, that is, reproductive rights of the women would not include free abortion. If this was the case, this ruling would most likely be contested by pro-choice supporters, same as the adoption of Act 2/2010 was contested by pro-lifers. Both positions deserve to be considered but the general abortion debate surpasses the object of this paper. From the legal perspective, this second outcome would be consistent with previous constitutional doctrine that considered the life of the unborn child should be protected and only restricted in case there is a conflict of rights, in which case prevalence might be given to other rights. The question then would be to determine under which circumstances should other rights prevail over the right to life of the unborn child. Pregnancies due to rape or endangering the life of the pregnant woman have been within the circumstances allowing the abortion in former Spanish legislation. What about the presence of a 'serious impairment'? As we have mentioned above, it seems difficult to maintain the constitutional doctrine pointing to economic reasons to limit a fundamental human right, since Spain has accepted the social model of disability underlying the CRPD.

The third outcome would be formally consistent with the CRPD. However, in order to comply with the CRPD it will not suffice with formal equality (i.e. being given the same deadlines to terminate any pregnancy). Discrimination towards disabled foetuses comes also from the health care practice. If this scenario was to be confirmed, the NIPT could have an extraordinary impact in the discriminatory practices. We shall explore in detail this scenario in our conclusions.

\section{The NIPT and the vicious circle}

What are the challenges of NIPT? According the IBC: 'The potential ethical disadvantages of NIPT can be summarized as routinization and institutionalization of the choice of not giving birth to an ill or disabled child. (...) there is the risk that pregnant women with a positive result don't await the validation of the result through invasive diagnostics, but immediately choose to abort the embryo or foetus, without adequate counselling about the relevance of the detected

Rodríguez Díaz, B, Mission Impossible? Preventing discrimination on grounds of disability of foetuses with Down syndrome in Spain after the emergence of non-invasive prenatal testing, International Journal of Discrimination and the Law XX (X), pp. 1-22. Copyright (C) [2020] (Rodríguez Díaz, B). DOI: [10.1177/1358229120902654] 
abnormality. Also, women may feel pressured to submit to such screening. They might be stigmatized if they refuse to take the test'. (IBC, 2015, par. 89)

Returning to the situation in Spain, provided the formal discrimination regarding TOP in art. 15 Act $2 / 2010$ is eventually removed, we would still face the mentioned challenges. As NIPT can provide an early $99 \%$ accurate result and they are being increasingly used in the public healthcare system, they could lead to a higher number of terminations of DS foetuses in the legal deadline without karyotype confirmation (Borrell, 2018) and without stating the cause of the termination. If this was the case, preventing and monitoring disability-selective abortion would be extremely difficult.

In some states of the USA such as North Dakota or Ohio, abortion on grounds of a DS diagnose has been banned. The practical implications of this solution make it unlikely to be followed in Spain. If abortion is to keep being considered a fundamental right of the woman in the first 14 weeks of the pregnancy, the actual reasons leading to a termination belong to the internal sphere of the expectant woman and any evidence provided by the health professionals could be easily disregarded. Besides, the banning of terminations on grounds of disability raises important moral and legal questions exceeding the object of this paper: why should we protect prenatal life? Is it legitimate to protect a collective (foetuses with DS) by positively discriminating them? Could we consider this special protection is required as the unborn population with DS are experiencing a sort of 'genocide' (López Barahona, 2016)? Why not protecting every foetus? What happens if the termination takes place because the unborn child doesn't have the desired sex? Is sex-selective abortion acceptable? As prenatal testing, and NIPT in particular, provides wide genetic information, what would be the limit to accept selective terminations: a missing toe, the colour of the eyes, the number of foetuses? We cannot enter into this crucial debate in this paper, but it is very much needed. Let us recall the IBC reflection on this:

'Many fear that the widespread use of NIPT as general screening may induce 'eugenic' use, even when the state is not involved. The adding up of a lot of individual choices to the 'acceptability' of aborting certain kinds of embryos or foetuses brings forward a societal phenomenon, which resembles a kind of eugenics in the search for a 'perfect child' (...) no one shall be subjected to discrimination based on genetic characteristics and that individuals should be respected in their uniqueness and diversity'. (IBC, 2015, par. 93).

What can be done to prevent selective terminations that constitute discrimination on grounds of disability? A complete ban of abortion in Spain doesn't look likely to happen neither restricted to disabled foetuses. Besides, it has been argued that banning selective abortion would do nothing to ease the bias that leads to the selective abortion - and could even reinforce it: 'the underlying assumption is that unless people are legally prohibited from aborting foetuses [with] disabilities, they will inevitably do so' (Graham, 2018).

If we are not to remove the choice between terminating a pregnancy or carrying it to term, the main thing to do to prevent disability-selective abortion is to influence this choice, to make the choice "real": 'Disabled people have argued that when a woman decides to abort a disabled foetus, she is not so much choosing as being constrained to take such a decision.' (Morris, 1991, p.66). Facing those constraints requires 'to challenge ingrained attitudes' (Bunbury, 2019, p. 40) towards disabled foetuses, and in particular with DS.

The best way for it is to change the communication of the diagnose. This requires both training professionals (compulsory under art. 4.1.i CRPD) and involving the civil society (persons with disabilities or their representative organisations) in the monitoring process (art. 16 CRPD). Why?

Rodríguez Díaz, B, Mission Impossible? Preventing discrimination on grounds of disability of foetuses with Down syndrome in Spain after the emergence of non-invasive prenatal testing, International Journal of Discrimination and the Law XX (X), pp. 1-22. Copyright (C [2020] (Rodríguez Díaz, B). DOI: [10.1177/1358229120902654] 
According Jotkowitz and Zivotofsky (2010, p. 150), 'studies have shown that physicians are not well trained on how to counsel a pregnant woman whose prenatal screen suggest a high probability of DS or other congenital abnormalities'. Besides, 'women are unprepared to make prenatal decisions about whether to abort a foetus with DS for a number of reasons. Among them are: societal pressure to have "normal" children, a disapproving view of people with disabilities, concern for legal liability among physicians, a lack of informed consent prior to genetic testing and a failure of non- judgmental pre-abortion counselling'.

Most healthcare professionals present the diagnose of DS with sympathy and even encouraging termination. Language plays an important role in the communication process and often the information accompanying the test gives no option for choice. The State must make sure the health professionals are trained to offer a balanced communication of the diagnose, with the support of the DS organisations.

We support a pro-information approach, to offer a more balanced portrait of the disability at the point of diagnosis (Graham, 2018), not hiding the challenges the DS people face but ending with the biases against DS. What are these biases? According Korenromp et al. (2007) the reasons why a DS child might not be wanted by prospective parents are: fear the burden would be too heavy for the child himself ( $83 \%)$ and he would never be able to function independently $(92 \%)$; fear they will be too much of a burden for them as parents (64\%), for their non-disabled children (73\%) or for their relationship (55\%); disappointment that the child will not meet the prospective life they have thought of, etc. However, there is empirical evidence of just the opposite: the percentage of people with DS declaring themselves happy with their lives, the way they look and who they are is $99 \%$ (Skotko et al., 2011a, p. 17); the siblings of people with DS show love (97\%) and pride $(87 \%)$ for their sibling with DS and even think they are a better person because of their brother or sister with DS (88\%) (Skotko et al. 2011b, p. 18-20); 99-97\% of parents express love and pride towards their children with DS (Skotko et al., 2011c, p. 21), considering their family has been enriched positively with their child with DS (Serrano Fernández and Izuzquiza Gasset, 2017, p. 90) and not affecting negatively marital functioning (Van Riper et al., 1992). Many autobiographical books (such as Beck, 1999; Groneberg, J.G, 2008, Soper KL 2009) are a testimony of change and happiness for having them. There is a huge contrast between expectations and reality as the study of How et al. $(2018$, p. 7$)$ visibly shows, regarding the experience of the fathers of children with DS:

Rodríguez Díaz, B, Mission Impossible? Preventing discrimination on grounds of disability of foetuses with Down syndrome in Spain after the emergence of non-invasive prenatal testing, International Journal of Discrimination and the Law XX (X), pp. 1-22. Copyright (C) [2020] (Rodríguez Díaz, B). DOI: [10.1177/1358229120902654] 


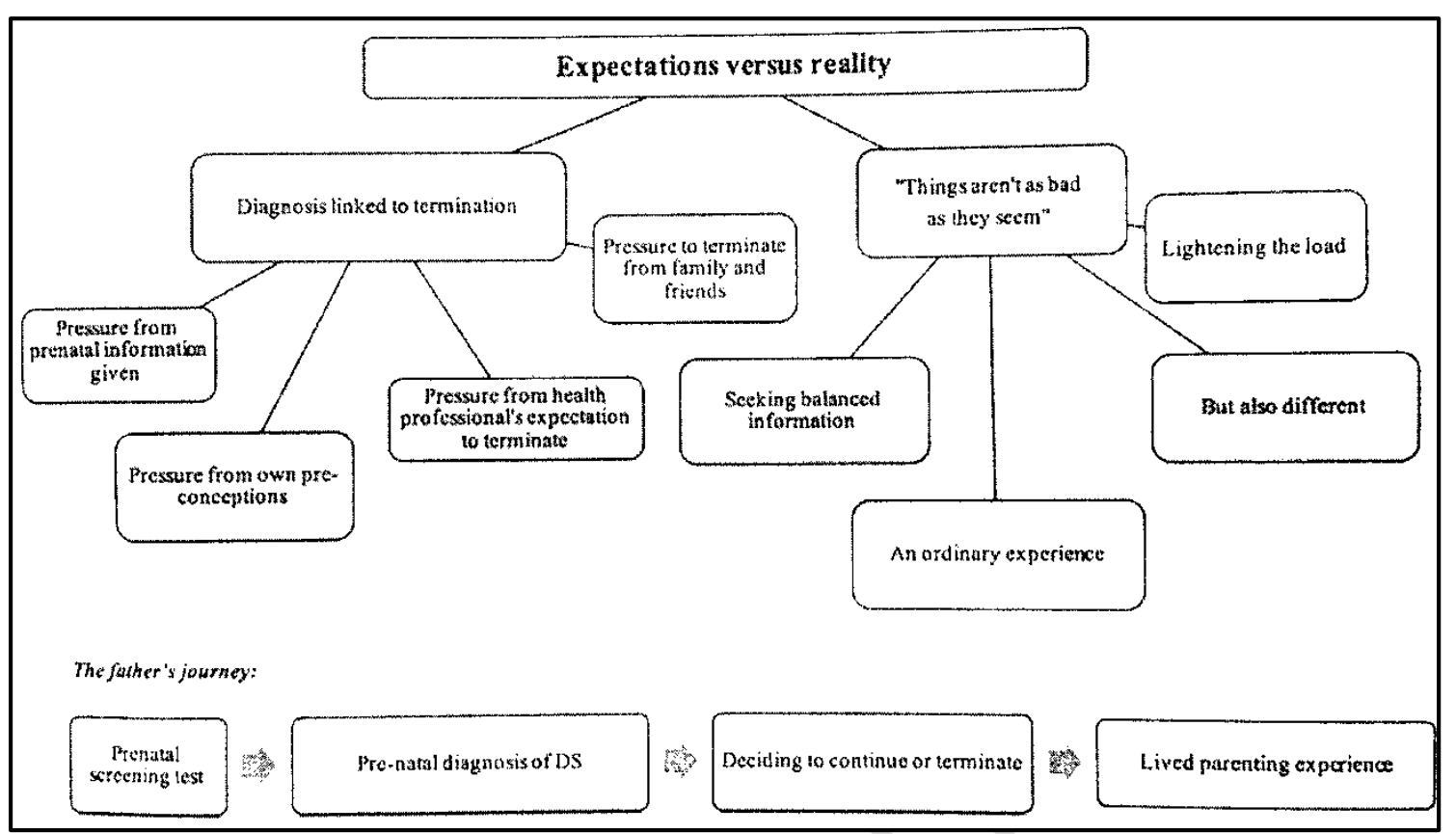

Figure 1: Journal of Intellectual Disabilities: reproduced with permission from SAGE, How et al., 2018.

Most authors consider that biases against people with DS are a strong motivating factor lying behind the high rates of selective abortion. Within them, Chris Kaposi (2018a) proposes to "choose Down syndrome", that is, to undo the bias against DS: 'we don't need new laws; we just need more people to choose to have such children' (Kaposi, 2018b). He argues that 'stigma and biased ways of thinking have actually been a primary cause of the push for prenatal testing and the high rates of termination, rather than being an effect of these practices' (Kaposi 2018a, p. 115).

We argue that there is a vicious circle as the biases against DS not only influence the prospective parents' decisions but also the legislation and health care routine programmes in Spain and vice versa. The idea of a vicious circle is also given by a well-known DS scholar, Jesús Flórez: 'The cycle starts with a general negative attitude towards DS ingrained in society. It promotes the NIPT as a simple way to detect it. As the testing is currently performed and oriented towards abortion, it increases the pressure to abort and we can understand the termination figures provided by statistics and extensively shown by social media. This fact reinforces the negative vision society has about DS. All this has an impact when making an informed decision. How could we find a counterweight to balance the scale so parents can take a well-informed decision? There is only one way: showing what means to raise a child with DS and that is something only parents with this experience can provide, and to show the reality of what people with DS can become, with their intrinsic values and their strengths and weaknesses' (Flórez, 2018, p. 50, author's translation). How et al. (2018, p. 15) clearly illustrate this idea as follows: 


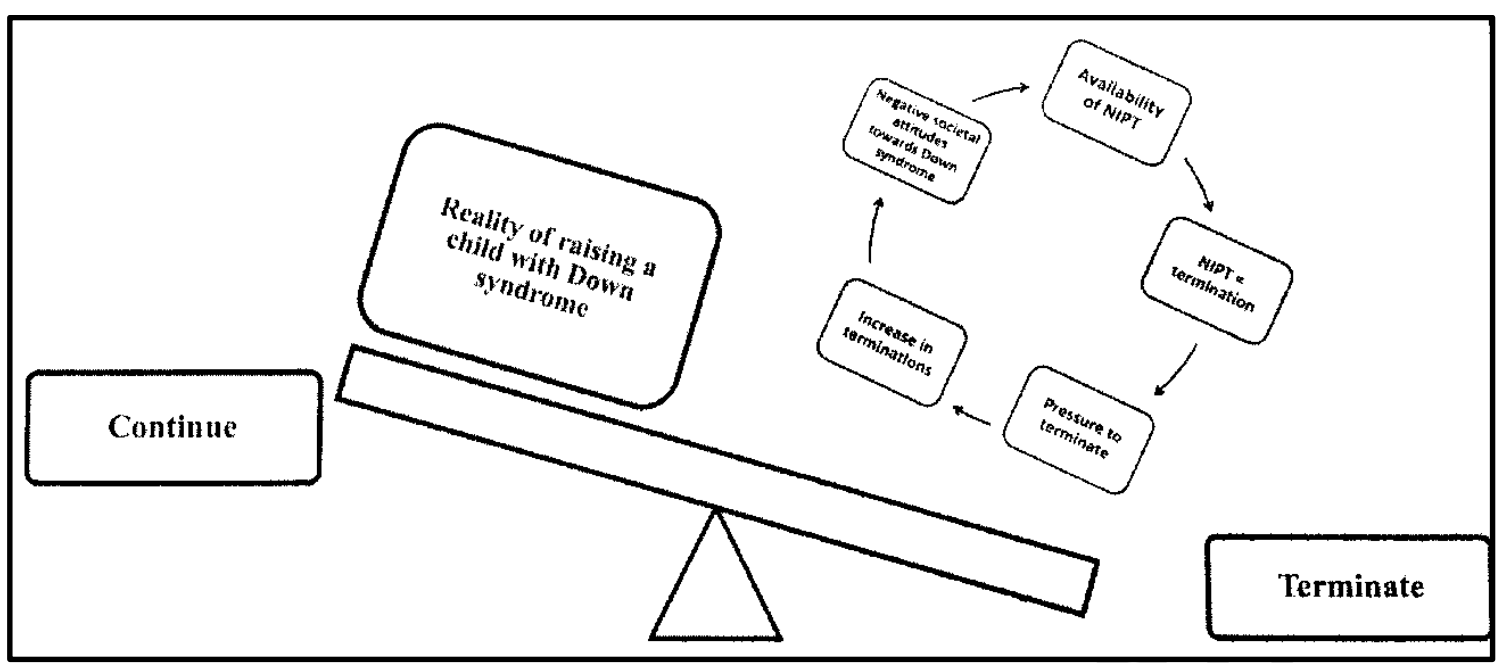

Figure 2: Journal of Intellectual Disabilities: reproduced with permission from SAGE, How et al., 2018.

As we can see, the main counterargument is providing actual information about the 'reality of raising a child with DS'. However, 'contact with parents in similar situations is an underused and maybe undervalued way of helping those clients' (Korenromp et al., 2007). Hence, 'More work on investigating the satisfactions associated with parenting a child with Down syndrome needs to be done. This is important in order that a balanced perspective can be provided to families who are beginning their lives as a family with a child with Down syndrome.' (Cuskelly et al., 2009, p. 108).

Additionally, in order to influence the vicious circle from the point of depart of legislation, we must acknowledge the influence of legislation in changing attitudes. Although law struggles 'to transform societal attitudes that exist' (Bunbury, 2019, p. 31), there are successful examples, such as the adoption of the Disabled Persons (Employment) Act 1944 in the UK that 'provoked as a result changes in attitudes towards employing disabled people' (Bunbury, 2019, p. 33).

Therefore, we consider with Bunbury that a disability, and DS in particular, should be seen as 'positive and central part of their identity' and thus 'the emphasis should focus on accepting that each individual has different needs which is unique (Herring, 2013) and perhaps should now be incorporated into legislation which may assist in transforming attitudes and challenging barriers that limit inclusion. (...) It is clear that by changing the law, attitudes will follow. Where the law changes, people's attitudes will generally change, and society will generally perceive disability as the «new normal»' (Bunbury, 2019, p. 41).

\section{Conclusions}

For our conclusions, we are going to assume that the Spanish TOP legislation will only be modified as required by the CRPD Committee, that is, that the same deadline will apply for any foetus regardless of any impairment, but it will still be considered a woman's right in the first fourteen weeks of the pregnancy. Should this scenario be confirmed, there are two possible solutions:

First: as suggested by Kaposi, one solution could be to refuse to expand the coverage of NIPT. 'Public health screening programs are typically designed as a way of reducing the incidence of

Rodríguez Díaz, B, Mission Impossible? Preventing discrimination on grounds of disability of foetuses with Down syndrome in Spain after the emergence of non-invasive prenatal testing, International Journal of Discrimination and the Law XX (X), pp. 1-22. Copyright (C) [2020] (Rodríguez Díaz, B). DOI: [10.1177/1358229120902654] 
certain diseases within a population. If a disease can be diagnosed, it can be treated; or, in the case of infectious diseases, transmission can be prevented. But when it comes to prenatal testing for DS, the only intervention currently available to reduce the incidence of this condition is pregnancy termination. A public-health-style screening program using NIPT would strongly imply that the government, as a representative of the public, has adopted the goal of eliminating people with DS. This message is strongly discriminatory' (Kaposi, 2019). While we consider this argument to be completely right, we need to bear in mind (as Kaposi does) the advantages of the NIPT, and the accuracy and safety, in avoiding the risk of miscarriage. It is not the existence of the NIPT that contributes to discrimination towards people with DS, rather it's the misuse of the NIPT. Having a prenatal diagnose can help prospective parents to adapt to the unexpected and unknown and to get ready for the coming challenges. As Dixon, we do not propose the elimination of prenatal testing, but rather 'that the genetic testing and counselling should not be biased against the birth of children with disabilities. Genetic testing and counselling should not convey directly or indirectly the message that the lives of persons with disabilities are worth less than other lives, or that the only practical alternative is to prevent their existence through abortion' (Dixon, 2008, p 5). A study by How et al. (2018, p.17) shows that fathers of children with DS only considered NIPT valuable 'if accompanied by balanced information about Down syndrome'.

Second: for as long as the Spanish healthcare system provides pregnancy care including prenatal techniques orientated to find out about chromosomal abnormalities such as DS before the legal deadline to terminate the pregnancy (hence the importance of the NIPT), it is the State responsibility:

a) to take all appropriate measures to put an end to all practices that constitute a discrimination on grounds of disability (art.4.1b CRPD), and thus to change the wording of the informed consent form provided to expectant mothers;

b) to make sure the public institutions comply with the CRPD (art.4.1.d CRPD) and to ensure the medical profession is not expressly or implicitly encouraging disabilityselective TOP but offering balanced information when communicating the diagnose. This obligation comprises the duty to 'promote the training of professionals' (art. 4.1.i CRPD) and to involve persons with DS through their representative organisations (compulsory under art. 4.3 CRPD). To fully comply with these obligations Spain should, among other things, provide solid genetics and ethics training for students in medical schools including communication of a prenatal diagnose; provide communication skills training for health care professionals involved in communicating the diagnose and, most importantly, ensure the communication process follow a protocol drafted with the participation of people with DS and their representative organisations;

c) to ensure private companies and organisations comply with the CRPD (art. 4.1.e). The NIPT are not yet offered universally to all expectant mothers in Spain but they still have the choice of accessing them privately. To comply with the CRPD Spain must make sure that the laboratories performing the NIPT are also communicating the diagnose of a disability such as DS in a balanced way, following a protocol drafted by the DS organisations;

d) to consider that the rulings awarding damages for "wrongful birth" constitute a breach of the CRPD as they imply life with a disability is less worthy and the birth of a child with a disability entrains a moral harm.

Rodríguez Díaz, B, Mission Impossible? Preventing discrimination on grounds of disability of foetuses with Down syndrome in Spain after the emergence of non-invasive prenatal testing, International Journal of Discrimination and the Law XX (X), pp. 1-22. Copyright (C) [2020] (Rodríguez Díaz, B). DOI: [10.1177/1358229120902654] 
To fight against the biases concerning DS is an obligation for the States signatories of the CRPD such as Spain. The Committee of the CRPD accordingly recommended Spain in April 2019 to "take measures, in partnership with self-advocacy organisations of persons with disabilities, to design, launch and maintain public awareness and media campaigns aimed at eliminating negative stereotypes towards persons with disabilities, promoting the recognition and respect of their rights and encouraging positive perceptions and enhanced social awareness about them in society" (par. 15).

To comply with this obligation there is much to be done. A few examples of different initiatives that had contributed to remove the prejudice against the DS include the documentary film by Sara Philips, "A world without Down syndrome" (BBC Two, 2016); the Instagram account "Pepitamola", with more than 240.000 followers, some of whom have later adopted babies with DS; the Goya-awarded best film "Campeones" about a basketball team of people with intellectual disabilities; websites such as Positive about Down Syndrome; autobiographic books by families of children with DS, e.g. 'Welcome to Holland' by E.P. Kingsley; naming baby Lucas Warren the first Gerber baby with DS; and many other initiatives through the social media.

The final goal of all these initiatives as well as of this study is to contribute to protect the rights of people with DS or other disabilities. NIPT are here to stay and most likely they will be increasingly used. Let us make sure they are not misused and that no one assumes that a life with a disability is less worth to be lived. Let us comply with the international commitments regarding the rights of people with disabilities. Let them live as we would do with anyone else. In their own words (Inclusion International, 2004): '(...) the lives of all future persons with disabilities, especially those with intellectual disabilities, are at risk because of developments in bioethics and prenatal testing for disability. For most persons with an intellectual disability, the disability is present before birth. (...) Society might soon be making a distinction between lives worth living and those not worth living. This is not an argument about a women's right to choose, it is about "our right" to be born and to be to be different. The presence of a disability must not be allowed to become a justification for the termination of life, nor must a disability justify changing the genetic make-up of a person. ${ }^{19}$

\section{Acknowledgements}

I would like to thank Prof. Andy Schmidt and the Journal of Intellectual Disabilities for authorising the reproduction of figures 2 and 6 from the article: 'We would have missed out so much had we terminated': What fathers of a child with Down syndrome think about current non-invasive prenatal testing for Down syndrome' (How et al., 2018).

\section{Declaration of Conflicting Interests}

The author declared no potential conflicts of interest with respect to the research, authorship, and/or publication of this article.

\section{Funding}

The author received no financial support for the research, authorship, and/or publication of this article. 


\section{Notes}

1. Act $2 / 2010$ of 3 March 2010 on sexual and reproductive health and voluntary termination of pregnancy.

2. $\mathrm{CRPD} / \mathrm{C} / \mathrm{ESP} / \mathrm{CO} / 1$, Concluding observations of the Committee on the Rights of Persons with Disabilities, 19 October 2011, paragraph 18.

3. $\mathrm{CRPD} / \mathrm{C} / \mathrm{ESP} / \mathrm{CO} / 2-3$, Concluding observations on the combined second and third periodic reports of Spain, 9 April 2019, paragraph 6b).

4. $\mathrm{CRPD} / \mathrm{C} / \mathrm{ESP} / \mathrm{CO} / 2-3$, paragraph $7 \mathrm{c}$ ).

5. CPH Post online. 'Down syndrome headed for extinction in Denmark', 20 October 2015, available at: http://cphpost.dk/news/down-syndrome-heading-for-extinction-indenmark.html (accessed 2 June 2019)

6. NHS Wales (2018) New screening for pregnant women to be offered in Wales, 30 April 2018, available at: http://www.wales.nhs.uk/news/48260 (accessed 18 July 2019)

7. NHS England (2018) NHS public health functions agreement 2018-19 Service specification no.16 NHS Fetal Anomaly Screening Programme - Screening for Down's Syndrome, Edwards' Syndrome and Patau's Syndrome (Trisomy 21, 18 \& 13). Available at: https://www.england.nhs.uk/wp-content/uploads/2017/04/Gateway-ref07837-180913-Service-specification-No.-16-NHS-FASP-Trisomy-screening-201819.pdf (accessed 18 July 2019).

8. Décision du 19 avril 2018 de l'Union nationale des caisses d'assurance maladie relative à la liste des actes et prestations pris en charge par l'assurance maladie, J.O. Republique Française (27 December 2018).

9. www.stopdiscriminatingdown.org

10. https://dontscreenusout.org/

11. [1985] Spain. Constitutional Court 53/1985.

12. [1985] Spain. Constitutional Court 53/1985.

13. We can see examples of this practice in the section 'Jurisprudencia Española en materia de Derecho Internacional Público', which is part of the leading journal Revista Española de Derecho Internacional.

14. 'Legal personality is acquired at the time of live birth, once the complete detachment of the mother's womb has taken place'. Art. 30 Spanish Civil Code.

15. United Nations Department of Economic and Social Affairs: Disability, CRPD. Available at: https://www.un.org/development/desa/disabilities/convention-on-therights-of-persons-with-disabilities.html (accessed 25 November 2019)

16. $\mathrm{CRPD} / \mathrm{C} / \mathrm{ESP} / \mathrm{CO} / 1$.

17. $\mathrm{CRPD} / \mathrm{C} / \mathrm{ESP} / \mathrm{CO} / 2-3$.

18. Informed Consent Protocol, "Programa de Cribado de Cromosomopatías", Autonomous Community of Madrid, Hospital Puerta de Hierro (Madrid), p. 17, author translation.

19. Summary of one the sessions of the drafting of the CRPD (13 January 2004). 


\section{References}

Allain J (2009) Treaty Interpretation and the United Nations Convention on the Rights of Persons with Disabilities. Belfast: Disability Action's Centre on Human Rights for People with Disabilities.

American College of Obstetricians and Gynecologists (ACOG) (2019) Prenatal Genetic Diagnostic Tests. Washington DC: ACOG. Available at: https://www.acog.org//media/For-Patients/faq165.pdf?dmc $=1 \&$ ts $=20190708 \mathrm{~T} 2052482806$ (accessed 16 September 2019)

BBC Two (2016) A World without Down's Syndrome? Dir. Clare Richards. London: Dragonfly Film and Television.

Bermejo-Sánchez L et al. (2011) Informe anual del ECEMC sobre vigilancia epidemiológica de anomalías congénitas en España: Datos del período 1980-2010, Boletín del ECEMC. Revista de Dismorfología y Epidemiología VI (1): 84-121.

Bermejo-Sánchez L et al. (2012) Informe de vigilancia epidemiológica de anomalías congénitas en España sobre los datos registrados por el ECEMC en el período 1980-2011. Boletín del ECEMC. Revista de Dismorfología y Epidemiología VI (2): 73-110.

Beck M (1999) Expecting Adam: a true story of birth, rebirth and everyday magic. New York: Berkley Books.

Borrell A (2018) A new comprehensive paradigm for Prenatal Diagnosis: to see the forest through the trees. Ultrasound in Obstetrics and Gynecology. Epub ahead of print February 2018. DOI: $10.1002 /$ uog. 19035

Borrell A and Stergiotou I (2015) Cell-free DNA testing: inadequate implementation of an outstanding technique. Ultrasound in Obstetrics \& Gynecology, 45(5): 508-11.

Bunbury S (2019) Unconscious bias and the medical model: How the social model may hold the key to transformative thinking about disability discrimination. International Journal of Discrimination and the Law 19(I): 26-47.

Chitty LS et al. (2016) Uptake, outcomes, and costs of implementing non-invasive prenatal testing for Down's syndrome into NHS maternity care: prospective cohort study in eight diverse maternity units. British Medical Journal. Epub ahead of print 4 July 2016. DOI: 10.1136/bmj.i3426.

Collins SL and Impey L (2011) Prenatal diagnosis: Types and techniques. Early Human Development 88 (1): 3-8.

Cuskelly M, Hauser-Cram P and Van Riper M (2009) Families of children with Down syndrome: What we know and what we need to know. Down Syndrome Education Online. doi:10.3104/reviews.2079

Dawkins R (2014) Abort it and try again. It would be immoral to bring it into the world if you have the choice, 20 August [Twitter]. Available at https://twitter.com/richarddawkins/status/502106262088466432?lang=en (Accessed 20 May 2019)

Dixon DP (2008) Informed Consent or Institutionalized Eugenics? How the Medical Profession Encourages Abortion of Fetuses with Down Syndrome. Issues in Law \& Medicine 24(1): 359.

Dommergues $\mathrm{M}$ et al. (2010) Termination of pregnancy following prenatal diagnosis in France: how severe are the foetal anomalies? Prenatal Diagnose 30: 531-539.

Florez J (2018) Síndrome de Down. Comunicar la noticia: El primer acto terapéutico. Santander: Fundación Iberoamericana Down 21.

Gil MM et al. (2015) Analysis of cell-free DNA in maternal blood in screening for fetal aneuploidies: updated meta-analysis. Ultrasound in Obstetrics and Gynecology 45: 249266.

Rodríguez Díaz, B, Mission Impossible? Preventing discrimination on grounds of disability of foetuses with Down syndrome in Spain after the emergence of non-invasive prenatal testing, International Journal of Discrimination and the Law XX (X), pp. 1-22. Copyright (C) [2020] (Rodríguez Díaz, B). DOI: [10.1177/1358229120902654] 
Gil MM et al. (2016) Clinical implementation of routine screening for fetal trisomies in the UK NHS: cell-free DNA test contingent on results from first-trimester combined test. Ultrasound in Obstetrics and Gynecology 47: 45-52.

Gracia Manzano V (2017) Asesoramiento genético y diagnóstico prenatal: aspectos éticos. Revista Bioética y Ciencias de la Salud 3 (4).

Graham R (31 May 2018) Choosing life with Down syndrome. Slate. Retrieved from https://slate.com/human-interest/2018/05/how-down-syndrome-is-redefining-the-abortiondebate.html (accessed 24 April 2019).

Gray KJ and Wilkins-Haug L (2018) Have we done our last amniocentesis? Updates on cell-free DNA for Down syndrome screening. Pediatric Radiology 48: 461-470

Groneberg JG (2008) Road map to Holland: how I found my way through my son's first two years with Down syndrome. New York: New American Library.

How B et al. (2018) 'We would have missed out so much had we terminated': What fathers of a child with Down syndrome think about current non-invasive prenatal testing for Down syndrome. Journal of Intellectual Disabilities XX(X): 1-20.

International Bioethics Committee (IBC) (2015) Report of the IBC on Updating its Reflection on the Human Genome and Human Rights. UNESCO. SHSNES/IBC-22/15/2 REV.2.

Jotkowitz A and Zivotofsky AZ (2010) The ethics of abortions for fetuses with congenital abnormalities. European Journal of Obstetrics \& Gynecology and Reproductive Biology 152: $148-151$.

Kaposi C (2018a) Choosing Down Syndrome. Ethics and New Prenatal Testing Technologies. Massachusetts: MIT Press.

Kaposi C (2018b) The Ethical Case for Having a Baby with Down Syndrome. New York Times, 16 April.

Kaposi C (2019) Non-invasive prenatal testing makes it simpler than ever to detect the condition, but does it amount to discrimination? Policy options. 22 April. Retrieved from https://policyoptions.irpp.org/magazines/april-2019/the-ethical-line-for-down-syndrometesting/?fbclid=IwAR1HyuYYdEr547q21MSyeBZdxgrO-opE4pNIWSxG_RMTygDMITnlG3qIiE (accessed 20 May 2019).

Klucznik S and Slepian H (2018) Iceland's Abortion Policy concerning Children with Down Syndrome: An Ethical Analysis. The Journal of Healthcare Ethics and Administration 4(1): 45-48.

Korenromp MJ et al. (2007) Maternal decision to terminate pregnancy in case of Down syndrome. American Journal of Obstetrics \& Gynecology 196(2): 149.e1 - 149.e11.

López Barahona M (21 March 2016), 'Podemos y debemos hablar de un genocidio de los niños con Síndrome de Down'. Infovaticana. Retrieved from https://infovaticana.com/2016/03/21/2714622/ (Accessed 20 April 2019).

Martínez-Pujalte AL (2016) Derechos en conflicto. Conflicto de derechos. Principales fricciones entre la Convención Internacional de los Derechos de las Personas con Discapacidad y la legislación española. In: Pérez Bueno LC and De Lorenzo R (eds) La Convención Internacional sobre los derechos de las personas con discapacidad 2006-2016. Una década de vigencia. Madrid: CERMI/ Cinca: 149-186.

Morris J (1991) Pride against Prejudice. Transforming attitudes to disability. London: The Women's Press.

Morris JK and Springett A (2014) The National Down Syndrome Cytogenetic Register for England and Wales: 2013 Annual Report. London: Queen Mary University of London, Barts and The London School of Medicine and Dentistry.

Natoli et al. (2012) Prenatal diagnosis of Down syndrome: a systematic review of termination rates (1995-2011). Prenatal Diagnosis 32: 142-153.

Rodríguez Díaz, B, Mission Impossible? Preventing discrimination on grounds of disability of foetuses with Down syndrome in Spain after the emergence of non-invasive prenatal testing, International Journal of Discrimination and the Law XX (X), pp. 1-22. Copyright (C) [2020] (Rodríguez Díaz, B). DOI: [10.1177/1358229120902654] 
Palacios A (2010) ¿Por qué el aborto eugenésico basado en discapacidad es contrario a la Convención Internacional de los Derechos de las Personas con Discapacidad? Revista Sindrome de Down (27): 50-58.

Paniagua Redondo R (1991) La recepción, publicación y rango normativo de los tratados internacionales en el ordenamiento jurídico español. Revista Jurídica de Cataluña 90 (4): 921-952.

Petersen AK et al. (2017) Positive predictive value estimates for cell-free noninvasive prenatal screening from data of a large referral genetic diagnostic laboratory. American Journal Obstetrics \& Gynecology 217: 691.e1-6.

Rodrigo AJ and Abegón M (2017) El concepto y efecto de los tratados internacionales de protección de los intereses generales de la comunidad internacional. Revista Española de Derecho Internacional 69 (1): 167-193.

Rodríguez Díaz B (2017) La aplicación de las reglas de interpretación de los tratados internacionales de la Convención de Viena de Derecho de los Tratados de 1969 a la Convención sobre los Derechos de las Personas con Discapacidad: el derecho a la vida de los fetos con síndrome de Down. Anuario Español de Derecho Internacional 33: 369-417.

Serrano Fernández L and Izuzquiza Gasset D (2017) Percepciones parentales sobre el impacto del síndrome de Down en la familia. Universidad de Salamanca. Siglo Cero 48 262(2): 8198.

Shakespeare T (2013) The social model of disability. In: Davis LJ (ed.) The Disability Studies Reader ( $4^{\text {th }}$ ed). New York and London: Routledge: 214-221.

Skotko BG (2009) With new prenatal testing, will babies with Down syndrome slowly disappear? Archives of Disease in Childhood 94: 823-826.

Skotko BG, Levine SP, Goldstein R (2011a) Self-perceptions from people with Down syndrome. American Journal of Medical Genetics part A. 155: 2360-2369.

Skotko BG, Levine SP, Goldstein R (2011b) Having a Brother or Sister with Down Syndrome: Perspectives from Siblings. American Journal of Medical Genetics part A. 155A(10): 2348-2359.

Skotko BG, Levine SP, Goldstein R (2011c) Having a Son or Daughter with Down Syndrome: Perspectives from Mothers and Fathers. American Journal of Medical Genetics part A. 155A(10): 2335-2347.

Smith M et al. (2014) A Case of False Negative NIPT for Down Syndrome- Lessons Learned. Case Reports in Genetics. Epub ahead of print 4 February 2014. DOI: http://dx.doi.org/10.1155/2014/823504

Soper KL (2009) The year my son and I were born: a story of Down syndrome motherhood and self-discovery. Guilford: GPP life.

Van Riper M, Ryff C and Pridham K (1992) Parental and family well-being in families of children with Down syndrome: a comparative study. Research in Nursing and Health 15(3): 227-235.

Vargas Aldecoa T (2015) Estudio de la comunicación del diagnóstico del Sindrome de Down de los profesionales sanitarios. $\mathrm{PhD}$ thesis. Universidad de Castilla la Mancha, Spain.

Vicie A, Hafner T et al. (2017) Prenatal diagnosis of Down syndrome: A 13-year retrospective study. Taiwanese Journal of Obstetrics \& Gynecology 56: 731-735.

World Health Organisation (WHO) (2018) Births with DS per 100000 live births. Available at https://gateway.euro.who.int/en/indicators/hfa_603-7120-births-with-downs-syndrome-per100-000-live-births/ (accessed 10 June 2019).

Rodríguez Díaz, B, Mission Impossible? Preventing discrimination on grounds of disability of foetuses with Down syndrome in Spain after the emergence of non-invasive prenatal testing, International Journal of Discrimination and the Law XX (X), pp. 1-22. Copyright (C) [2020] (Rodríguez Díaz, B). DOI: [10.1177/1358229120902654] 